Article

\title{
Social Sustainability Strategy across the Supply Chain: A Conceptual Approach from the Organisational Perspective
}

\author{
Mohammad Najjar ${ }^{1, * \mathbb{C}}$, Michael H. Small ${ }^{2}$ (D) and Mahmoud M. Yasin ${ }^{2}$ \\ 1 Department of Business Administration, An-Najah National University, Nablus 009709, Palestine \\ 2 College of Business and Technology, East Tennessee State University, Johnson City, TN 37614, USA; \\ smallm@etsu.edu (M.H.S.); mmyasin@etsu.edu (M.M.Y.) \\ * Correspondence: m.najjar@najah.edu; Tel.: +970-598-452-781
}

Received: 22 September 2020; Accepted: 9 December 2020; Published: 14 December 2020

\begin{abstract}
Much of the existing literature on the social aspects of sustainability in the supply chain has focused on dyadic buyer-supplier relationships. However, supply chains are much more extensive, featuring multi-tiered systems consisting of many interconnected sequential and parallel dyadic relationships; therefore, a more expansive and holistic approach to exploring the management and integration of social sustainability standards across the extended supply chain is desirable. This research attempts to help fill this void and considers the extent to which a series of sequential upstream and downstream supply chain partners, rather than only a focal organization's immediate suppliers and buyers, influence the formulation process of the social aspects of a sustainability strategy and the deployment of associated practices across the extended supply chain. Findings in the literature indicate that, inter alia, sustainability efforts in the supply chain are likely to be guided by stakeholders' sustainability desires/requirements, the geographical location of buyers and suppliers and the associated sustainability enforcement regulations and cultural norms, and the volume of trade between the buyer and supplier. This paper uses the results gleaned from a review of the literature to propose a conceptual framework for selection of sustainability strategy across the multi-tiered supply chain. Finally, we introduce a conceptual approach to the process of implementing and deploying the social aspects of sustainability strategies and practices across the supply chain using an integrated social-sustainability information management system (ISIMS).
\end{abstract}

Keywords: sustainable supply chain management; social sustainability; socially responsible supply chains

\section{Introduction}

Sustainability has become a major focus of businesses as they seek to prolong the lives of their organizations. Most of the research work concerning sustainability has centered on the economic and environmental dimensions and less attention has been paid to the social aspects of sustainability across the supply chain from the operational perspective [1-3]. The social dimension of sustainability in this research is primarily concerned with ensuring that organizations and their partners across the supply chain manage their operations in a way that promotes: health and safety, a supportive working environment, human rights standards, labor rights, and measures aimed at improving ethical practices at the workplace [4-7], while having a positive impact on the surrounding community along the supply chain. Noting the dearth of research on the social aspects of sustainability across the supply chain, several authors have made sustained calls for more research efforts in this area [2,3,7-10].

When sustainability is incorporated into the strategic objectives of an organization, operational and organizational performance measures and reporting requirements need to be expanded. In much 
the same way that the debate surrounding tradeoffs between cost and quality evolved in the late 20th century, current concerns are centered on the issue of how much attention and resources should be applied to attaining sustainability across the operations of supply chain partners and how expenditures on sustainability will affect the business organization's bottom line. Recognizing the need to rationalize the new reality of operating in systems that must deal with reducing costs, improving quality, and increasing flexibility in an environment that also honors environmental and social aspects of sustainability has led to organizational performance being operationalized using the "Triple Bottom Line (TBL)" concept suggested by Elkington [11]. This concept indicates that organizations can commit to a set of activities that will result in long-term competitive advantage, while having a positive effect on the economy, the environment, and society $[12,13]$.

However, most organizations are also integral partners in, sometimes, more than one supply chain. Hence, sustainable supply chain management has emerged in recent years as an important field of research [12,14-20]. It focuses on "the management of material, information and capital flows as well as cooperation among companies along the supply chain while taking goals from all three dimensions of sustainable development, i.e., economic, environmental and social, into account which are derived from customer and stakeholder requirements" [16]. Therefore, it is important that individual organizations also view their sustainability efforts in terms of their impact on the sustainability practices of their various multi-tiered supply chain partners, but, especially their immediate suppliers and buyers [21,22].

For example, textile manufacturers must be concerned that their suppliers are not contributing to the indiscriminate employment of child or forced labor across their operations. Similarly, producers of chemical substances should be concerned with how their downstream customers will use these products in their operations so they will not jeopardize the health and safety of their employees. Therefore, organizations should be willing to facilitate and support the sustainability practices of both their suppliers and customers at the operational level. Figure 1 outlines a typical supply chain for manufactured products. Suppose, for example, that an end customer for a product has determined that he/she would be unwilling to purchase the product if child labor was utilized in the manufacture of any of its components or in the processing of the product at any stage of the supply chain. Then, the social sustainability practices for each of the supply chain partners would prohibit the use of child labor. Thus, the distributor/retailer would have to ensure that the manufacturer is compliant with this requirement. Subsequently, the manufacturer would have to ensure that its suppliers were adhering to this requirement and so on.

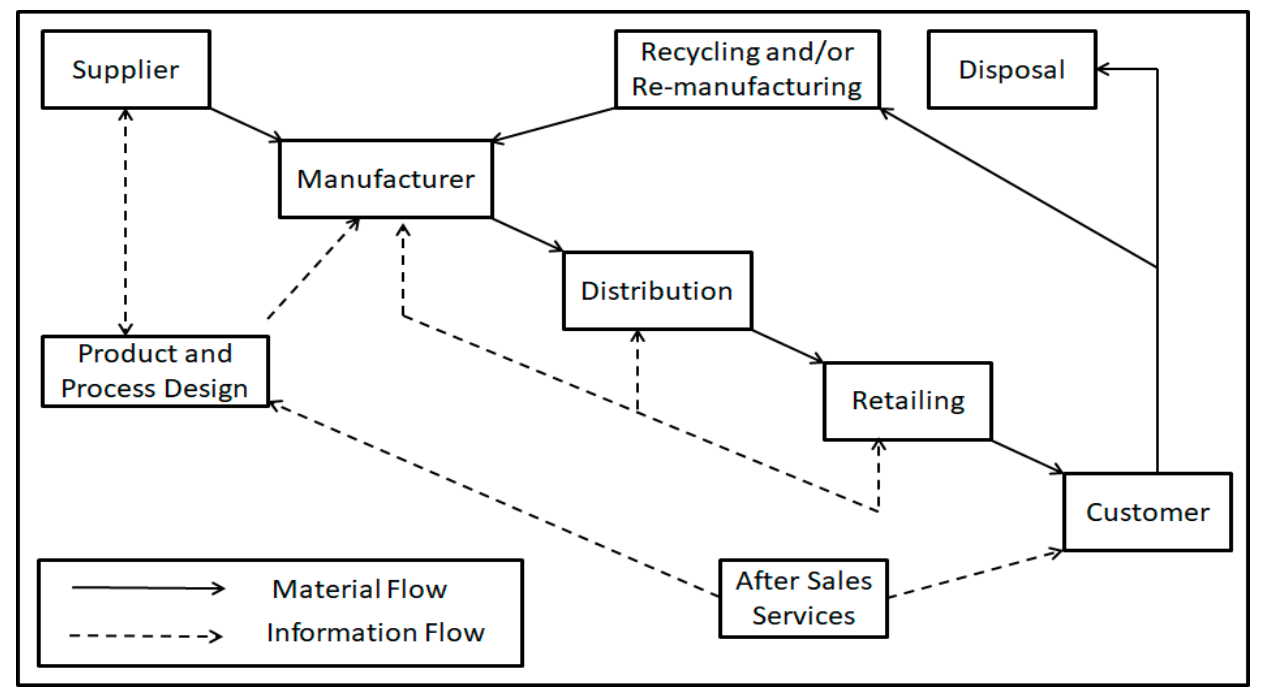

Figure 1. Supply Chain Cycle for Manufactured Products.

Organizations have adopted different practices to embed the social aspects of sustainability across the operations of their supply chains partners $[23,24]$. Some practices may enforce the social 
aspects of sustainability and strictly monitor suppliers and customers operations (e.g., physical audits), while others may promote self-development and a shared sustainability vision across the supply chain (e.g., codes of conduct). Although these practices offer valuable insights into the potential risks and inefficiencies of immediate suppliers and customers [25], unethical behaviors across other levels of the supply chain are still occurring [3,26].

Compared to economic and environmental issues, social issues across the operations of supply chain partners are more likely to be deemphasized. Monitoring the social aspects of sustainability in a multi-tiered supply chain becomes more difficult because focal organizations have less visibility of the operations of their upstream and downstream supply chain partners beyond their immediate suppliers or buyers $[27,28]$. Tertiary supply chain partners may jeopardize an organization's operations, and monitoring the entire supply chain is costly and may not even be feasible [3,28-31]. Therefore, there is a growing recognition in the literature of the importance of developing a sustainability strategy that considers the social aspects in order to help counteract supply chain disruptions and to ensure that the operational performance of suppliers and customers is aligned with the focal organization's sustainability strategies $[3,7,10,32,33]$.

It has been suggested that there are different factors that an organization should consider when they attempt to achieve their sustainability objectives. Factors such as the geographical dispersion of suppliers, the location of suppliers and customers (in developing or developed countries), the influential power of buyers, and the pressure exerted by different stakeholder groups $[2,3,6,8,9,20,22,34-41]$ are considered to be important. These factors must be taken into account when organizations seek to implement successful and effective sustainability strategies and to promote the social aspects across the operations of their supply chain partners.

In summary, sustainable supply chain management has added an important stream to research on supply chain management. However, most research on extending the social aspects of sustainability across the supply chain has attempted to focus on the different practices adopted by business organizations to ensure their immediate suppliers' and customers' compliance. Limited attention has been given to the integration of sustainability from a strategic perspective. Moreover, there are still substantial research areas that need to be addressed to investigate how organizations seek to manage the social aspects of sustainability across their supply chains. Consequently, this research attempts to explore how organizations design the social aspects of sustainability strategies and deploy these strategies across their extended supply chains. We seek to answer the following research questions:

1. How do organizations design and integrate the social aspects of sustainability into their strategies? 2. How do organizations implement and deploy the social aspects of sustainability across the operations of their multi-tiered supply chain partners?

This research study makes various contributions to the growing literature on sustainable supply chain management. Firstly, drawing on prior sustainable supply chain management literature, we identify various supply chain social sustainability practices. Secondly, information provided in the literature review is distilled to assist focal organizations in the supply chain in designing sustainability strategies as well as ways to integrate these strategies with those of immediate suppliers and buyers. Finally, we introduce a conceptual approach to implementing and deploying the social aspects of sustainability across the supply chain using an integrated social-sustainability information management system (ISIMS).

\section{Literature Review}

Given the objectives of this study, this research focuses exclusively on the social rather than the economic or environmental dimensions of sustainability in supply chain management. Consequently, we investigate three themes in the literature: (a) A definition of sustainable supply chain management; (b) The impact of different stakeholder groups on the adoption of the social aspects of sustainability across the supply chain, and (c) Investigation of the different practices that have 
been utilized to ensure the adoption of social sustainability aspects across the operations of supply chain partners.

\subsection{Sustainable Supply Chain Management}

The term sustainability was delineated in 1987 by the World Commission on Environment and Development more generally referred to as the Brundtland Commission which defined sustainability as "an approach to progress which meets the needs of the present without compromising the ability of future generations to meet their own needs" [42]. In a more recent development, the United Nations adopted "Agenda 2030 for Global Sustainable Development" at a September 2015 UN summit. Agenda 2030 includes 17 Sustainable Development Goals (SDGs) that aim to promote sustainability across all nations but emphasizes the need to prioritize the sustainable development of smaller more-dependent nations. Another methodology that can be used to assess an organization's sustainability performance is the Social Life Cycle Assessment (S-LCA). It focuses on evaluating the social and sociological aspects of a product, while analyzing its positive and negative impact on people along the lifecycle from raw material extraction to final disposal.

In the operations and supply chain management fields, the term sustainability is more often associated with corporate social responsibility and business ethics. While corporate social responsibility is concerned with an organization's contribution to the surrounding community or community philanthropy $[14,43,44]$, ethics is concerned with giving attention to issues related to elements such as reducing bribery and corruption $[14,45,46]$.

In the last two decades, there has been a growing interest among organizations to outsource parts of their operations to suppliers in developing countries in an attempt to reduce costs and increase profits. To remain competitive, suppliers in developing countries started to focus more attention on cost reduction, sometimes to the detriment of maintaining ethical standards and acceptable human rights practices $[1,40,42,43]$. Increasingly, organizations are being held accountable for the operations of their suppliers $[3,6,36,44]$. Therefore, the term sustainability has started to emerge as an integral factor in the operations and supply chain management literature $[7,19,45-50]$.

In the literature encompassing operations and supply chain management, sustainability has been operationalized using the "Triple Bottom Line (TBL)" concept [11], which seeks to elevate the importance of environmental, social, and economic dimensions in measuring the performance of an organization, and, by extension, the performance of all partners in the supply chain. Attention to the TBL leads to the supply chain having a positive impact on the environment and society, while also focusing on the organization's economic viability and its long-term competitive advantage [12,13]. Hence, no discussion about sustainability across the supply chain is complete without paying due consideration to the impact of supplier and buyer actions and operations on the social impact of the chain $[11,17,21,23,24,27,51]$.

Therefore, the Seuring and Muller [16] definition of sustainable supply chain management emphasizes the importance of cooperation among companies along the supply chain to achieve the economic, environmental, and social goals of sustainable development. They also emphasize that these goals are derived from customer and stakeholder requirements. Consequently, supply chain partners that adopt sustainability goals should have the impetus to extend their sustainability practices and principles across their supply chains to improve the chain's reputation and to gain economic and competitive benefits in their industry $[7,10,12,23,41]$, while at the same time protecting the environment and ensuring social growth without influencing human well-being.

Most of the research concerning sustainability across the supply chain has focused on the economic and environmental dimensions and less attention has been paid to the social aspects [1-3]. The social dimension of sustainability across the supply chain is primarily concerned with ensuring that supply chain partners manage their operations in a way that promotes: health and safety, a supportive working environment, human rights standards, labor rights, and measures aimed at improving ethical practices at the workplace [4-7], while having a positive impact on the surrounding community along the supply 
chain. This research focuses on these aspects and explores how business organizations attempt to extend (and manage) these aspects across the operations and production activities of their supply chain partners. The "Agenda 2030 for Sustainable Development" is a comprehensive approach to achieving sustainable development across different nations. Indeed, the social dimension of the TBL concept and the expansion of social aspects across the operations of supply chain partners will ultimately contribute to the achievement of the SDGs in the 2030 agenda, specifically related to: (Goal 3: Good Health and Well-being, Goal 5: Gender Equality, Goal 8: Decent Work and Economic Growth, Goal 10: Reduced Inequality, and Goal 12: Responsible Consumption and Production).

\subsection{The Impact of Stakeholders on the Adoption of the Social Dimension of Sustainability across the Supply Chain}

Due to the unethical practices that have emerged across the different supply chains during the last few years, it is not surprising that different stakeholder groups have given increasing attention to monitoring supply chains' operations more closely $[9,25,41]$.

Firstly, customer pressure has been recognized as a major driving force for the adoption of social aspects of sustainability across the supply chain. A prime area of concern for customers has been the importance of establishing proper working environment and fair labor laws across the operations of supply chain partners $[7,25,41,52-55]$. Customers' satisfaction motivates organizations to adopt and extend the different aspects of social sustainability across their supply chains [9]. Increased customer consciousness can influence the legitimacy and credibility of the entire supply chain and the competitive position of the organization in the industry $[7,56,57]$. Therefore, there is a growing need to design a sustainability strategy that aligns the operations of internal functional departments (purchasing, marketing, etc.), while integrating customers' and stakeholders' expectations with the organization's sustainability agenda $[30,45,58]$.

Although governmental regulations have gained scant attention in the literature [7], most developed nations already have well entrenched laws and regulation to support the aims of the social dimension of sustainability [27]. The UN Global Compact was developed to encourage and support economic, social and environmental sustainability, especially among developing nations $[1,26,35,50,59-61]$. The literature suggests that there is a lack of legislation and regulations to support the implementation of the social dimension of sustainability concept in its broader sense across developing nations. In this regard, Najjar et al. [29] suggest that while governments in developing countries may lack the ability and initiative to enforce such regulations on local suppliers, there is also the possibility that there may be a lack of pressure and enforcement from supply chain partners in the more developed countries.

Non-governmental organizations (NGOs) such as the Fair Labor Association (FLA) have also emerged during the last few years. They monitor human rights abuses across the operations of supply chain partners and can act as a watchdog [7,47], stimulating organizations to adopt the social aspects of sustainability across their extended supply chains. One of the major consequences of the global dispersion of suppliers is that many organizations view these NGOs as a primary source of independent monitoring of the social sustainability practices and performance of their supply chain partners $[3,7,38]$. Since disclosures in NGO reports can influence a business organization's reputation and image, many suppliers are willing to cooperate with the NGOs and make any proffered adjustments to their practices $[3,7,12,62]$. Koberg and Longoni [3] highlighted that organization interaction and collaboration with NGOs can lead to positive sustainability outcomes across global supply chains.

Investors may also play a critical role in a focal organization's decision to adopt the different aspects of the social dimension of sustainability. Investors may affect financial performance of the organization, and therefore they have significant power to influence an organization's decision to adopt the different social elements of sustainability [27,41]. In addition, investors nowadays take the pursuit of sustainability as an important prerequisite for investment in an organization. Furthermore, they appear to be more willing to invest in an organization whose sustainability indicators have strategic relevance [63]. 
Advances in media technology have also contributed to the utility of enacting the social aspects of sustainability in organizations and in the supply chain. In the new transparent and connected world, streaming information to different stakeholder groups is becoming faster [7,64]. Media channels can also influence consumers' purchasing habits, which will eventually affect an organizations' economic performance [60]. As a consequence, media channels play an important role in mobilizing organizations to adopt social sustainability practices and extend sustainability across the supply chain $[18,47,65]$.

Maignan et al. [43] (p. 642) have stated that "stakeholder initiatives may be designed to demonstrate commitment to a particular standard or value, disclose wrong-doing, spread negative images of the firm, change company practices, and/or hinder the proper functioning of the firm." Their dynamic expectations should be taken into account when designing effective sustainability strategies across the supply chain. As a consequence, organizations have adopted a set of practices to meet stakeholders' dynamic expectation, while ensuring suppliers' compliance, in order to protect their credibility and reputation, while at the same time ensuring social growth without influencing human well-being. The different social sustainability practices will be discussed in the following section.

\subsection{Managing the Social Aspects of Sustainability in the Supply Chain}

In the socially sustainable supply chain management context, business organizations seek to improve their supply chain performance, while at the same time examining the impact of immediate suppliers' activities and operations on workers and the surrounding community. However, the principle of bounded rationality suggests that organizations have limited omniscience of their extended supply chains. A customer, in Figure 1, should not be responsible for ensuring that the raw material supplier (four-levels upstream) adheres to its expectations. For the customer's expectation to be met, the customer should only have to ensure that the retailer of the product met the requirement. It would be the responsibility of the retailer to ensure that the distributor met the requirement, and so on up the supply chain. The literature points to three major practices that can be used by buyers to ascertain the social sustainability practices of their suppliers. These practices are: (1) Third-party certifications management systems, (2) Physical audits and assessment, and (3) Supplier codes of conduct.

Third Party Certificates, such as SA8000 and ISO 45001, are widely used across organizations [7]. They are issued by external entities and attest that suppliers have met a list of practices that merit the relevant accreditation $[1,3,16,22,40,66]$. Certificates might be industry-specific or multi-industry $[3,62]$. Industry-specific certificates focus on a single industry and address a particular set of issues in this industry such as REACH (Registration, Evaluation, Authorization, and Restriction of Chemicals); whereas multi-industry can be applied to different industrial sectors and addresses a wider set of social issues such as SA8000. Klassen and Vereecke [57] argued that end-consumers usually favor multi-industry certificates, whereas business-to-business markets prefer industry-specific certificates. In addition, the type of product chain is also an important factor that should be taken into account when an organization selects a standard. For example, textile and food product chains favor standards that focus on human and labor rights, whereas chemical product chains favor standards that give specific attention to health, safety, and working environment since they work with chemical substances and hazardous materials/processes. Since there are different stakeholders' expectations, certificates allow suppliers to avoid the need to conform to multiple and overlapping expectations $[3,67]$.

An alternative to third-party certification is an assessment of supplier operations and social sustainability standards during physical visits to the supplier site, using a physical on-site audit and assessments $[7,19,37]$. On these visits, the auditors perform such tasks as data collection and screening, and employee interviews to explore issues related to the buyer's social sustainability requirements. A major concern about physical audits is that they focus on identifying areas of non-compliance rather than on finding solutions that will alleviate the non-compliance $[64,68]$. In addition, business organizations may find it difficult to perform physical audits with geographically dispersed suppliers due to the associated higher costs $[8,57,69,70]$. 
Another means of monitoring supplier socially sustainable conduct is using Suppliers Codes of Conduct ( $\mathrm{CoC})$. This is a method that is more likely to be used by large corporations [71]. The CoC is prepared by the buying organization and contains guidelines and principles underlying the values and cultural norms of the organization and any principles covered by international and national conventions $[2,10,18,20,22,35,72,73]$. The buyer shares its CoC with all relevant suppliers as a means of creating a background for common expectations and to eliminate any potential areas of misunderstanding $[5,37,38,74,75]$.

Although several practices have been adopted to effect the different aspects of the social dimension of sustainability [25], unethical behaviors across the supply chain are still recurring [3,26]. A cursory review of the findings in the extant literature indicates that there are considerable challenges facing these organizations in achieving sustainability objectives across their supply chains. This may include: (a) the geographical dispersion of suppliers; (b) whether or not suppliers or buyers are located in developing or developed countries; (c) the size and influential power, as measured by volume of supplier sales to buyers or volume of purchases from suppliers; and (d) the pressure exerted by different stakeholder groups $[2,3,6,8,9,20,22,34-41]$.

Social issues in global supply chains are more likely to be hidden because many suppliers and customers operate outside the purview of the focal organization $[27,28]$. Tertiary supply chain partners may jeopardize a focal organization's operations, and monitoring the entire supply chain may be costly and may not always be feasible [3,28-31]. Furthermore, supply chain partners located in developing countries may lack enough skills and expertise to implement the social aspects of sustainability [9]. They operate under different regulations and cultural norms [6,40]. In addition, a partner "around the corner" can be reached easily through site audits, whereas distant partners located in developing countries, for example, are less reachable [6]. Equally important, power can facilitate or inhibit the adoption of sustainability across the supply chain [27]. Indeed, the bargaining power of a focal organization can influence a supplier's orientation toward sustainability in order to protect against negative disclosure [7].

\section{Developing a Socially Sustainable Supply Chain Strategy}

Given the general discourse on the social dimension of sustainability and the various ways of measuring and managing suppliers operations across the supply chain, we are now in a position to illustrate how these items can be incorporated into a sustainability strategic planning process. Our proposed approach for developing the sustainability component of the corporate strategy is outlined in Figure 2. Social aspects must be addressed across the operations of supply chain partners. The major focus of the social dimension of sustainability in a focal supply chain organization is to promote: worker health and safety, working environment, human rights including labor rights, while having a positive impact on the surrounding community along the supply chain $[11,14,17,21,23,24,27,46,51]$.

As a member of the supply chain, the focal organization should identify the social impacts and consequences of its supply chain operations/activities on human well-being (including worker health and safety, working conditions, human right practices, etc.). The S-LCA can be considered a useful methodology in this aspect. The S-LCA assesses the organization's social aspects and sustainability performance and the positive and negative impact of its products and services on people well-being along the lifecycle (i.e., the supply chain from raw material extraction to final disposal). It can be used to determine which of the area(s) of social sustainability focus is/are more important to stakeholders and which aspects may prevail across the operations of supply chain partners. It considers the requirements of local and international laws and regulations and the potential expectations from associated NGOs. In addition, the methodology takes into account the geographical location, political attributes, and country regulations to assess an organization's and its supply chain partners' social impacts. A list of sustainability aspects will be generated, which should be taken into account during the development of sustainability strategy and practices in order to improve the performance of the entire supply chain (including the focal organization) and the well-being of stakeholder groups. 


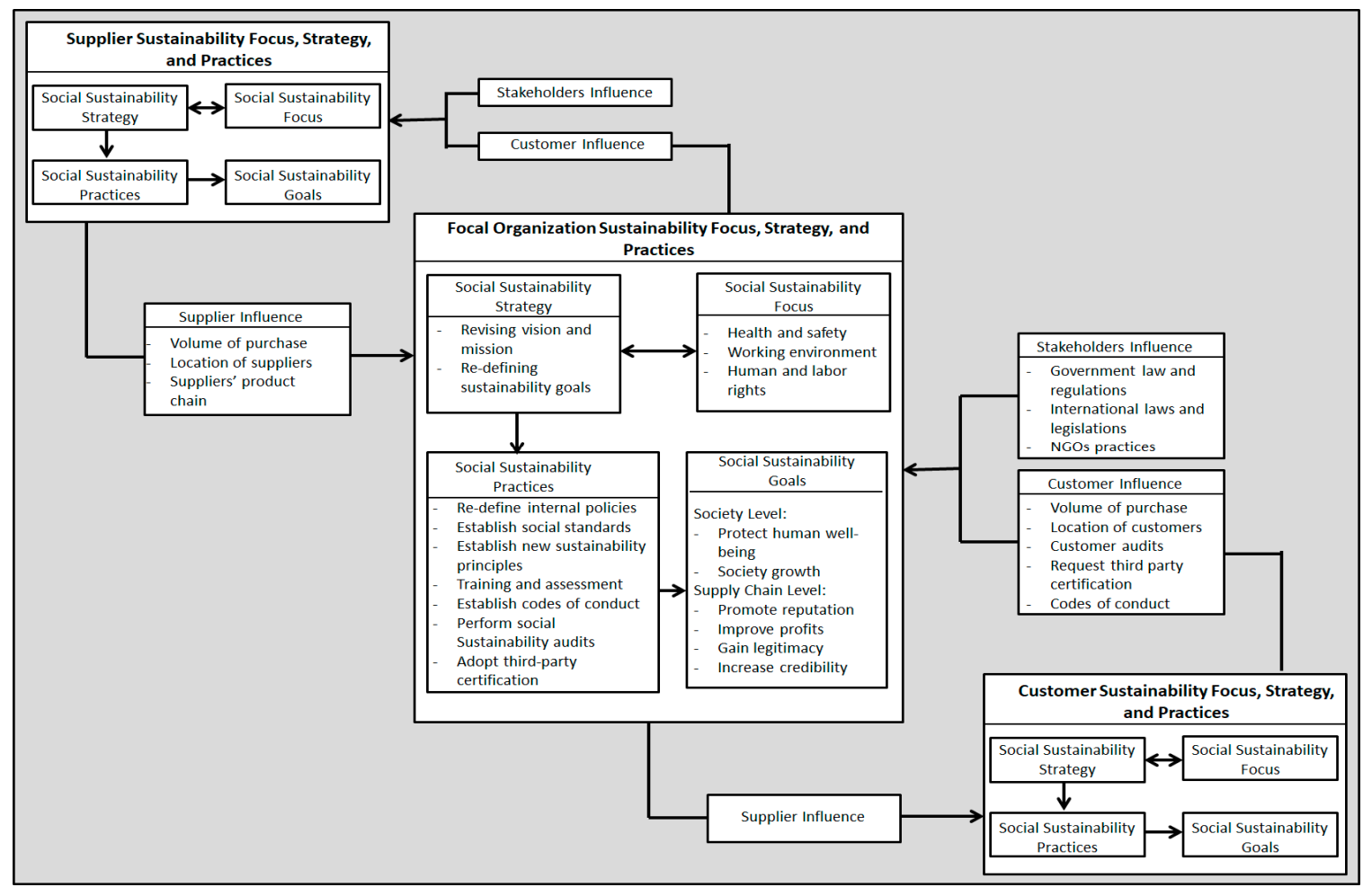

Figure 2. Developing the Social Aspects of Sustainability Strategy in the Supply Chain.

All the challenges surveyed in this literature review should be taken into account when organizations are seeking to adopt and implement effective sustainability strategies and to deploy the social dimension of sustainability across their supply chains. These issues will also have an impact on the type of information system that should be adopted to ensure that the focal organization and its supply chain partners can easily enter and access critical sustainability and performance information that can be used to assess the attainment of strategic supply chain sustainability objectives. Clearly, it will also be important to ensure that supply chain partners provide credible information on their sustainability practices and performance to ensure the integrity of output of the information systems.

To establish effective sustainability strategies while taking into account the different challenges and constraints that exist across the supply chain, this research implicitly follows the Quality Function Deployment (QFD) methodological approach [76-78]. The QFD is a structured approach; it encompasses several steps that transfer challenges, constraints, and stakeholders' requirements into product, process, and strategy improvements [76-82]. To illustrate, we will consider a focal organization in the supply chain which may function as both a buyer and then subsequently a supplier. Indeed, any partner in a supplier chain except the original raw materials supplier and the end customer fulfills the dual role of a buyer and a supplier.

Firstly, and based on the QFD approach, different challenges have been identified representing the different requirements that should be addressed by an organization's sustainability strategy. As a member of the supply chain, the focal organization will have to consider the requirements, preferences, and the pressure exerted from the different stakeholder groups (voice of stakeholders). As sustainability consciousness has increased during the last few years, stakeholders (including customers and suppliers) may request for more transparency and traceability across the supply chain. They may determine which of the areas of the social dimension of sustainability focus (health and safety, human rights, etc.) are important to them. In addition, the focal organization may consider the local and international laws and the expectations of different NGOs.

Furthermore, organizations should consider the power influence of their immediate suppliers and customers, measured by volume of supplier sales to buyers or volume of purchases from 
suppliers. The literature suggests that the focal organization strategy is more likely to be influenced by customers that represent a substantial proportion of the focal organization's sales than minor customers. Furthermore, in an integrated supply chain it is also likely that the focal organization can learn from the sustainability experience and performance of its suppliers. Suppliers that provide a significant proportion of the focal organization's purchases in volume or dollar value will exert more influence on the focal organization's sustainability strategy.

In addition, the geographical dispersion of supply chain partners, and the location of partners in developed or developing countries, defines cultural norms and regulations that are followed. In addition, a close partner can be monitored easily through site visits, whereas distant suppliers and customers are more difficult to reach. They may also lack the skills and expertise to implement sustainability. In fact, understanding stakeholders' requirements and the existing constraints in the supply chain will help in designing a strategy that will achieve the desired outcomes.

Next, the organization may start to establish a sustainability strategy, with strategic objectives tying back to stakeholders' requirements and supply chain constraints and challenges. The strategic objectives, which reflect the different requirements and challenges, will trickle down into operational practices in order to manage the activities, operations, and sustainability practices of supply chain partners. The organization will have to determine which specific practices should be enacted to meet its sustainability objectives and focus. The organization can choose specific practices, such as establishing sustainability policies, social standards, codes of conduct, staffing the sustainability function, training employees on sustainability-objectives, -practices, and -performance assessment. In its role as a buyer, the organization will also have to determine which assessment techniques it will use to measure the sustainability performance of its suppliers.

As sustainability consciousness has increased during the last few years, stakeholders (including customers and suppliers) may request for more transparency and traceability across the supply chain. To promote traceability and transparency, the focal organization may implement information systems that connect suppliers, customers, and other stakeholders in order to share, collect, and analyze sustainability data, as will be shown in the following section.

As indicated in Figure 2, most partners along the supply chain will play a dual role of buyer or supplier in the supply chain, and, therefore, the same analysis as was used for the focal organization can be applied at each level of the supply chain.

\section{Social-Sustainability Information Management System}

With the general outline of the development of the sustainability strategy process at the various levels of the supply chain given in Figure 2, including the interrelationships between successive suppliers and buyers in the chain, the following conceptual approach can be used to integrate the planning of a supply-chain wide sustainability strategy with associated social sustainability practices.

Integration of the social aspects of a sustainability strategy and practices along the supply chain depends on the ability and desire of the various partners to share social issues and sustainability information with their immediate buyers and suppliers and ultimately with all the partners in the supply chain. Figure 3 presents a framework for supply chain partners to share their sustainability objectives and performance with their partners in the chain.

As a first step, each partner will have to implement sustainability teams and sustainability management systems which incorporate the information required to complete Figure 2. The team can follow up the sustainability strategy inside the focal organization. It will feed the sustainability management system with the required information to be shared with top management to take proper decisions or with other stakeholders (including customers and suppliers) to align the sustainability initiatives across the supply chain. 


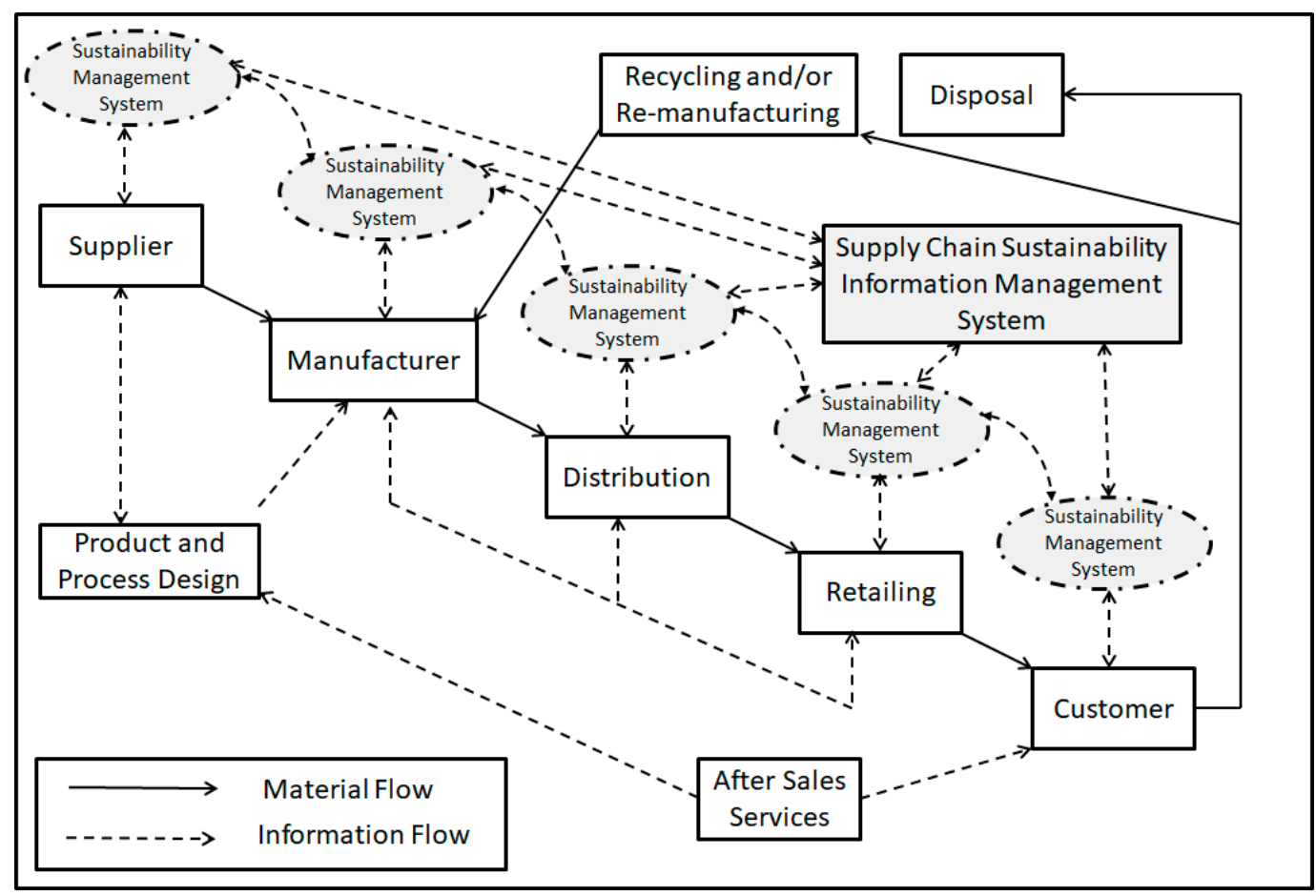

Figure 3. A Framework for Implementing a Global Supply Chain Sustainability Strategy.

Preferably, the social-sustainability management system will be a component of an enterprise resources management system (ERP). Each organization's sustainability management system will have a database that contains information on social sustainability focus, strategies, practices, and goals. The database will also contain pertinent information relative to customer, stakeholder, and competitive influences and best practices derived from both suppliers and customers. It will also store third-party reports, audits, and Codes of Conduct and relevant training manuals. Third party evaluators and NGOs may be given access to limited data which is required for any supply-chain approved reporting. Data from all the sustainability management systems will be stored in a supply-chain wide system called the integrated social-sustainability information management system (ISIMS) which can be a stand-alone system or, preferably, a component of the supply chain's enterprise resources planning system.

\section{Conclusions}

Sustainable supply chain management has been gaining increasing attention during the last few years. However, limited attention has been given to how organizations integrate the social aspects of sustainability into their existing strategies and operational practices. Consequently, this research attempts to explore this gap. It seeks to explore how organizations should design sustainability strategies and how they attempt to extend (and manage) these aspects across the operations and production activities of their supply chain partners. The social dimension of sustainability across the supply chain is primarily concerned with ensuring that supply chain partners manage their operations in a way that promotes: health and safety, a supportive working environment, human rights standards, labor rights, and measures aimed at improving ethical practices at the workplace, while at the same time ensuring social growth without influencing human well-being along the supply chain. The expansion of social aspects across the operations of supply chain partners will ultimately contribute to the achievement of the SDGs in the 2030 agenda.

The findings of this conceptual study make various contributions to the growing literature sustainable supply chain management. Firstly, the existing literature has focused on the dyadic buyer-supplier relationship to manage the social aspects of sustainability [2]. Social issues are likely to be hidden and a multi-tiered supply chain reduces transparency even further because many suppliers 
operate outside the purview of the focal firm [27,28]. Indeed, the conceptual frameworks in this research give a holistic perspective of the management and integration of the social dimension of sustainability across multi-tiered supply chains.

Secondly, the existing literature has focused on the different practices to extend social dimension of sustainability $[1,6,8,10,26,37,83-85]$ and the impact of different stakeholder groups $[9,20,25,41,55]$. This research addresses the management of the social aspects of sustainability from a strategic perspective. Information provided in the literature review is distilled to assist focal organizations in the supply chain in designing the sustainability strategy process as well as ways to interrelate these strategies with those of suppliers and buyers. According to the conceptual framework in Figure 2, focal organizations can employ the S-LCA to identify stakeholders' requirements and the social aspects that are important to them (e.g., health and safety, child labor, etc.). In addition, focal organizations may need to revise their strategic focus, missions, and objectives to meet stakeholders' requirements and considering the challenges that exist across the supply chain. Focal organizations may adopt different practices to embed the elements of sustainability into their own operations and they may also need to adopt other practices to extend, manage, and monitor their suppliers' and customers' sustainability initiatives.

Thirdly, previous research has called for the exploration of the different challenges that may affect the adoption of the social dimension of sustainability $[3,6,29,84]$. The research has identified several contingent factors that should be taken into account in order to design an effective sustainability strategy. Consistent with findings from previous research $[2,10,22,41,55]$, the focal organization should consider the impact of stakeholders. The research findings suggest exploring and understanding stakeholders' expectations, while reflecting these expectations on the focal organizations' sustainability strategy in order to gain legitimacy and credibility. Indeed, sustainability strategies must consider local and international laws, potential impacts from associated NGOs, and international standards and competitive pressures related to social responsibility. Potential impacts resulting from stakeholder influences may have to be included in the company's sustainability practices. In addition, the framework in Figure 2 highlights the importance of identifying the volume of purchase with suppliers and customers and the level of dispersion of suppliers to enable the focal organization to design an effective sustainability strategy. Moreover, assessing the relative volume of purchase from buyers or suppliers may help to predict the willingness of partners to adapt new changes, whereas knowledge of the location and dispersion of suppliers and customers will help to identify and define the cultural norms and local regulations that must be adhered to by supply chain partners.

Finally, we introduced a conceptual framework in Figure 3 for deploying and integrating sustainability strategies and practices across the supply chain using an integrated social-sustainability information management system (ISIMS). This ISIMS facilitates information sharing among partners within the supply chain in order to take proper actions and design effective sustainability strategies. It improves communication and supports supply chain integration, which will not only affect cost and efficiency [86,87], but also have a positive impact on the sustainability performance of the entire supply chain. Since the social dimension of sustainability depends mainly on the exchange of information among partners, the findings suggest that the location and dispersion of suppliers (operating under different cultural norms and regulatory aspects) can have an impact on the level of sustainability integration across the supply chain.

Stakeholders, mainly customers and NGOs, are requesting more visibility of the supply chain. Indeed, the ISIMS can facilitate the transfer of information to stakeholders, increasing supply chain transparency and credibility. The ISIMS sustainability data can be accessible to supply chain partners and stakeholders, providing continuous monitoring and transparent operations. The ISIMS can be considered a modest step towards establishing a sustainable blockchain [87-89] that takes into account sustainability dimensions. The blockchain digitally connects supply chain partners, allowing them to exchange real-time information about their products and processes [87-90]. A blockchain will allow more transparency and visibility of the supply chain, while ensuring better stakeholders and customer 
engagement. However, the effectiveness of the blockchain depends on the willingness of participating partners to share credible and sensitive information about their social and ethical practices.

This research has several managerial implications. Our conceptual framework provides a starting point to understand how to design an effective supply chain sustainability strategy. Different practices have been identified and the role played by stakeholders has been explored. Practices and stakeholders are not disconnected from strategy [12]. Instead, organizations must explicitly link stakeholders' expectations to existing sustainability strategies and embed different practices to extend the social aspects of sustainability across the supply chain. Finally, ISIMS also provides managers with an integrative approach to manage the social dimension of sustainability across the supply chain. It provides managers with a salient picture of how an organization and its partners may implement a socially sustainable supply chain.

Our research is not free of limitations. Firstly, our findings and conceptual frameworks are based on the insights and lessons learned from previous research. While our literature review is fairly extensive and representative, it was not exhaustive, so there may be other potential key factors that influence the adoption and performance of the social dimension of the sustainability strategy and practices that may not have been uncovered in this research. Secondly, the findings and the conceptual frameworks advanced in this research are based on the literature focusing only on the social aspects of sustainability across the supply chain. Other research that focuses on incorporating the other components of the TBL (economic and environmental) would provide a more comprehensive view of the adoption of sustainability in the supply chain, but this was beyond the purpose and scope of this paper. It is our belief, however, that by separating out the social aspect of sustainability, we have been able to develop a framework that is illustrative of the process that may have some utility in examining economic and environmental sustainability either separately or in combination with social dimension of sustainability. Such approaches will provide fertile areas of research for future studies.

Consequently, researchers can enrich and validate the conceptual frameworks. Case studies and survey research can be utilized to help in advancing the underlying issues, allowing researchers to arrive at more valid and meaningful results. In addition, future research may validate the findings and the conceptual frameworks utilizing the TBL concept. This will help researchers and practitioners to achieve a more comprehensive understanding of the requirements for achieving and maintaining sustainability across the multi-tiered supply chain.

It must be noted that this paper is not a primer on developing prescribed superior sustainability strategies for each partner in a supply chain. Rather, it is focused on developing an effective process for each organization to consider and incorporate the sustainability goals and objectives of their immediate buyers and suppliers into their sustainability strategy. Repeating this throughout the supply chain should result in a fully integrated sustainability strategy that is geared towards meeting the needs not only of the chain's end customers, but of all partners at all levels of the chain. The ISIMS proposed will provide the flexibility for partners in the chain to recognize and react in real time to any shifts in customer or supplier conditions or requirements.

Finally, the ISIMS as a blockchain digitally connects stakeholders and partners across the supply chain. Therefore, future research may investigate the implications of adopting blockchain technology on the promotion of social and environmental aspects. In addition, future research may explore the different barriers, e.g., the dispersion of partners across geographical locations and cultural and regulatory differences, may limit the effectiveness of blockchain systems.

Author Contributions: All authors have contributed to the development of the manuscript. The analysis of literature has been performed by M.N. The conceptual frameworks have been developed by all authors. The first draft has been prepared by M.H.S. and M.M.Y. and the final manuscript with intensive discussion of the findings and contribution has been developed by M.N. Submission, review, and editing have been performed by M.N. and M.M.Y. All authors have read and agreed to the published version of the manuscript.

Funding: This research received no external funding.

Conflicts of Interest: The authors declare no conflict of interest. 


\section{References}

1. Ageron, B.; Gunasekaran, A.; Spalanzani, A. Sustainable supply management: An empirical study. Int. J. Prod. Econ. 2012, 140, 168-182. [CrossRef]

2. Roy, V.; Schoenherr, T.; Charan, P. The thematic landscape of literature in sustainable supply chain management (SSCM) A review of the principal facets in SSCM development. Int. J. Oper. Prod. Manag. 2018, 38, 1091-1124. [CrossRef]

3. Koberg, E.; Longoni, A. A systematic review of sustainable supply chain management in global supply chains. J. Clean. Prod. 2019, 207, 1084-1098. [CrossRef]

4. Carter, C. Purchasing and Social Responsibility: A Replication and Extension. J. Supply Chain Manag. 2004, 40, 4-16. [CrossRef]

5. Mamic, I. Managing Global Supply Chain: The Sports Footwear, Apparel and Retail Sectors. J. Bus. Ethics 2005, 59, 81-100. [CrossRef]

6. Busse, C.; Schleper, M.C.; Niu, M.; Wagner, S.M. Supplier development for sustainability: Contextual barriers in global supply chains. Int. J. Phys. Distrib. Logist. Manag. 2016, 46, 442-468. [CrossRef]

7. Köksal, D.; Strähle, J.; Müller, M.; Freise, M. Social sustainable supply chain management in the textile and apparel industry-A literature review. Sustainability 2017, 9, 100. [CrossRef]

8. Najjar, M.; Shahwan, R.M.M.; Yasin, M.M. Exploring Social Responsibility across the Supply Chain: A Supplier's Perspective. J. Compet. Stud. 2018, 26, 10-23.

9. Gong, M.; Gao, Y.; Koh, L.; Sutcliffe, C.; Cullen, J. The role of customer awareness in promoting firm sustainability and sustainable supply chain management. Int. J. Prod. Econ. 2019, 217, 88-96. [CrossRef]

10. Miemczyk, J.; Luzzini, D. Achieving triple bottom line sustainability in supply chains: The role of environmental, social and risk assessment practices. Int. J. Oper. Prod. Manag. 2019, 39, 238-259. [CrossRef]

11. Elkington, J. Cannibals with Forks: The Triple Bottom Line of the 21st Century; New Society Publishers: Stoney Creek, CT, USA, 1998.

12. Carter, C.; Rogers, D. A framework of sustainable supply chain management: Moving toward new theory. Int. J. Phys. Distrib. Logist. Manag. 2008, 38, 360-387. [CrossRef]

13. Carter, C.; Easton, P.L. Sustainable supply chain management: Evolution and future directions. Int. J. Phys. Distrib. Logist. Manag. 2011, 41, 46-62. [CrossRef]

14. Carter, C.; Jennings, M. Social responsibility and supply chain relationships. Transp. Res. Part E Logist. Transp. Rev. 2002, 38, 37-52. [CrossRef]

15. Ciliberti, F.; Pontrandolfo, P.; Scozzi, B. Investigating corporate social responsibility in supply chains: A SME perspective. J. Clean. Prod. 2008, 16, 1579-1588. [CrossRef]

16. Seuring, S.; Muller, M. From a literature review to a conceptual framework for sustainable supply chain management. J. Clean. Prod. 2008, 16, 1699-1710. [CrossRef]

17. Pagell, M.; $\mathrm{Wu}, \mathrm{Z}$. Building a more complete theory of sustainable supply chain management using case studies of 10 exemplars. J. Supply Chain Manag. 2009, 45, 37-56. [CrossRef]

18. Leire, C.; Mont, O. The implementation of socially responsible purchasing. Corp. Soc. Responsib. Environ. Manag. 2010, 17, 27-39. [CrossRef]

19. Marshall, D.; McCarthy, L.; Heavey, C.; McGrath, P. Environmental and social supply chain management sustainability practices: Construct development and measurement. Prod. Plan. Control 2015, 26, 673-690. [CrossRef]

20. Najjar, M.; Shahwan, R.M.M.; Yasin, M.M. Supply Chain Social Sustainability: From the Perspective of a Supplier Operating under a Restricted Operating Environment. Compet. Forum 2017, 15, 8.

21. Nakamba, C.C.; Chan, P.W.; Sharmina, M. How does social sustainability feature in studies of supply chain management? A review and research agenda. Supply Chain Manag. Int. J. 2017, 22, 522-541. [CrossRef]

22. Sodhi, M.S.; Tang, C.S. Corporate social sustainability in supply chains: A thematic analysis of the literature. Int. J. Prod. Res. 2018, 56, 882-901. [CrossRef]

23. Croom, S.; Vidal, N.; Spetic, W.; Marshall, D.; McCarthy, L. Impact of social sustainability orientation and supply chain practices on operational performance. Int. J. Oper. Prod. Manag. 2018, 38, 2344-2366. [CrossRef]

24. Beske-Janssen, P.; Johnson, M.P.; Schaltegger, S. 20 years of performance measurement in sustainable supply chain management-what has been achieved? Supply Chain Manag. Int. J. 2015, 20, 664-680. [CrossRef] 
25. Gualandris, J.; Klassen, R.D.; Vachon, S.; Kalchschmidt, M. Sustainable evaluation and verification in supply chains: Aligning and leveraging accountability to stakeholders. J. Oper. Manag. 2015, 38, 1-13. [CrossRef]

26. Lu, R.X.A.; Lee, P.K.C.; Cheng, T.C.E. Socially responsible supplier development: Construct development and measurement validation. Sustain. Dev. Manuf. Serv. 2012, 140, 160-167. [CrossRef]

27. Eriksson, D.; Svensson, G. Elements affecting social responsibility in supply chains. Supply Chain Manag. Int. J. 2015, 20, 561-566. [CrossRef]

28. Choi, T.Y.; Dooley, K.J.; Rungtusanatham, M. Supply networks and complex adaptive systems: Control versus emergence. J. Oper. Manag. 2001, 19, 351-366. [CrossRef]

29. Najjar, M.; Small, M.H.; Yasin, M.M. Adopting and Extending Social Sustainability Practices across the Supply Chain. Compet. Forum 2019, 17, 105-113.

30. Awasthi, A.; Govindan, K.; Gold, S. Multi-tier sustainable global supplier selection using a fuzzy AHP-VIKOR based approach. Int. J. Prod. Econ. 2018, 195, 106-117. [CrossRef]

31. Amaeshi, K.M.; Osuji, O.K.; Nnodim, P. Corporate Social Responsibility in Supply Chains of Global Brands: A Boundaryless Responsibility? Clarifications, Exceptions and Implications. J. Bus. Ethics 2008, 81, 223-234. [CrossRef]

32. Krause, D.R. The antecedents of buying firms' efforts to improve suppliers. J. Oper. Manag. 1999, 17, $205-224$. [CrossRef]

33. Krause, D.R.; Handfield, R.B.; Tyler, B.B. The relationships between supplier development, commitment, social capital accumulation and performance improvement. J. Oper. Manag. 2007, 25, 528-545. [CrossRef]

34. Cramer, J.M. Organising corporate social responsibility in international product chains. J. Clean. Prod. 2008, 16, 395-400. [CrossRef]

35. Jiang, B. The effects of interorganizational governance on supplier's compliance with SCC: An empirical examination of compliant and non-compliant suppliers. J. Oper. Manag. 2009, 27, 267-280. [CrossRef]

36. Awaysheh, A.; Klassen, R. The impact of supply chain structure on the use of supplier socially responsible practices. Int. J. Oper. Prod. Manag. 2010, 30, 1246-1268. [CrossRef]

37. Ciliberti, F.; de Haan, J.; de Groot, G.; Pontrandolfo, P. CSR codes and the principal-agent problem in supply chains: Four case studies. J. Clean. Prod. 2011, 19, 885-894. [CrossRef]

38. Wu, Z.; Pagell, M. Balancing priorities: Decision-making in sustainable supply chain management. J. Oper. Manag. 2011, 29, 577-590. [CrossRef]

39. Walker, H.; Jones, N. Sustainable supply chain management across the UK private sector. Supply Chain Manag. Int. J. 2012, 17, 15-28. [CrossRef]

40. Zorzini, M.; Hendry, L.C.; Huq, F.A.; Stevenson, M. Socially responsible sourcing: Reviewing the literature and its use of theory. Int. J. Oper. Prod. Manag. 2015, 35, 60-109. [CrossRef]

41. Lechler, S.; Canzaniello, A.; Wetzstein, A.; Hartmann, E. Influence of different stakeholders on first-tier suppliers' sustainable supplier selection: Insights from a multiple case study in the automotive first-tier industry. Bus. Res. 2020, 13, 425-454. [CrossRef]

42. Brundtland, G. World Commission on Environment and Development. 1987. Available online: https://sustainabledevelopment.un.org/content/documents/5987our-common-future.pdf (accessed on 11 December 2020).

43. Maignan, I.; Hillebrand, B.; McAlister, D. Managing Socially-Responsible Buying: How to Integrate Non-economic Criteria into the Purchasing Process. Eur. Manag. J. 2002, 20, 641-648. [CrossRef]

44. van Marrewijk, M. Concepts and Definitions of CSR and Corporate Sustainability: Between Agency and Communion. J. Bus. Ethics 2003, 44, 95-105. [CrossRef]

45. Carter, C.; Jennings, M.M. The role of purchasing in corporate social responsibility: A structural equation analysis. J. Bus. Logist. 2004, 25, 145-186. [CrossRef]

46. Maloni, M.; Brown, M. Corporate Social Responsibility in the Supply Chain: An Application in the Food Industry. J. Bus. Ethics 2006, 68, 35-52. [CrossRef]

47. Campbell, J.L. Why would corporations behave in socially responsible ways? An institutional theory of corporate social responsibility. Acad. Manag. Rev. 2007, 32, 946-967. [CrossRef]

48. Koplin, J.; Seuring, S.; Mesterharm, M. Incorporating sustainability into supply management in the automotive industry-The case of the Volkswagen AG. J. Clean. Prod. 2007, 15, 1053-1062. [CrossRef] 
49. Quarshie, A.M.; Salmi, A.; Leuschner, R. Sustainability and corporate social responsibility in supply chains: The state of research in supply chain management and business ethics journals. J. Purch. Supply Manag. 2016, 22, 82-97. [CrossRef]

50. Chen, L.; Zhao, X.; Tang, O.; Price, L.; Zhang, S.; Zhu, W. Supply chain collaboration for sustainability: A literature review and future research agenda. Int. J. Prod. Econ. 2017, 194, 73-87. [CrossRef]

51. Freise, M.; Seuring, S. Social and environmental risk management in supply chains: A survey in the clothing industry. Logist. Res. 2015, 8, 2. [CrossRef]

52. Sarkis, J.; Gonzalez-Torre, P.; Adenso-Diaz, B. Stakeholder pressure and the adoption of environmental practices: The mediating effect of training. J. Oper. Manag. 2010, 28, 163-176. [CrossRef]

53. Foster, S.T., Jr.; Wallin, C.; Ogden, J. Towards a better understanding of supply chain quality management practices. Int. J. Prod. Res. 2011, 49, 2285-2300. [CrossRef]

54. Sarkis, J.; Zhu, Q.; Lai, K. An organizational theoretic review of green supply chain management literature. Int. J. Prod. Econ. 2011, 130, 1-15. [CrossRef]

55. Liu, L.; Zhang, M.; Hendry, L.C.; Bu, M.; Wang, S. Supplier Development Practices for Sustainability: A Multi-Stakeholder Perspective. Bus. Strategy Environ. 2018, 27, 100-116. [CrossRef]

56. Gopalakrishnan, K.; Yusuf, Y.Y.; Musa, A.; Abubakar, T.; Ambursa, H.M. Sustainable supply chain management: A case study of British Aerospace (BAe) Systems. Sustain. Dev. Manuf. Serv. 2012, 140, 193-203. [CrossRef]

57. Klassen, R.D.; Vereecke, A. Social issues in supply chains: Capabilities link responsibility, risk (opportunity), and performance. Int. J. Prod. Econ. 2012. [CrossRef]

58. Schneider, L.; Marcus Wallenburg, C. Implementing sustainable sourcing-Does purchasing need to change? J. Purch. Supply Manag. 2012, 18, 243-257. [CrossRef]

59. Park-Poaps, H.; Rees, K. Stakeholder Forces of Socially Responsible Supply Chain Management Orientation. J. Bus. Ethics 2010, 92, 305-322. [CrossRef]

60. Tang, C.S.; Zhou, S. Research advances in environmentally and socially sustainable operations. Eur. J. Oper. Res. 2012, 223, 585-594. [CrossRef]

61. Mani, V.; Gunasekaran, A.; Papadopoulos, T.; Hazen, B.; Dubey, R. Supply chain social sustainability for developing nations: Evidence from India. Resour. Conserv. Recycl. 2016, 111, 42-52. [CrossRef]

62. Mueller, M.; Gomes dos Santos, V.; Seuring, S. The contribution of environmental and social standards towards ensuring legitimacy in supply chain governance. J. Bus. Ethics 2009, 89, 509-523. [CrossRef]

63. Cheng, M.M.; Green, W.J.; Ko, J.C.W. The impact of strategic relevance and assurance of sustainability indicators on investors' decisions. Audit. J. Pract. Theory 2015, 34, 131-162. [CrossRef]

64. Teuscher, P.; Grüninger, B.; Ferdinand, N. Risk management in sustainable supply chain management (SSCM): Lessons learnt from the case of GMO-free soybeans. Corp. Soc. Responsib. Environ. Manag. 2006, 13, 1-10. [CrossRef]

65. Roberts, S. Supply Chain Specific? Understanding the Patchy Success of Ethical Sourcing Initiatives. J. Bus. Ethics 2003, 44, 159-170. [CrossRef]

66. Lee, K.-H.; Kim, J.-W. Current status of CSR in the realm of supply management: The case of the Korean electronics industry. Supply Chain Manag. Int. J. 2009, 14, 138-148. [CrossRef]

67. Reinecke, J.; Manning, S.; Hagen, O. von The Emergence of a Standards Market: Multiplicity of Sustainability Standards in the Global Coffee Industry. Organ. Stud. 2012. [CrossRef]

68. Spence, L.; Bourlakis, M. The evolution from corporate social responsibility to supply chain responsibility: The case of Waitrose. Supply Chain Manag. Int. J. 2009, 14, 291-302. [CrossRef]

69. de Bakker, F.; Nijhof, A. Responsible chain management: A capability assessment framework. Bus. Strategy Environ. 2002, 11, 63-75. [CrossRef]

70. Vurro, C.; Russo, A.; Perrini, F. Shaping Sustainable Value Chains: Network Determinants of Supply Chain Governance Models. J. Bus. Ethics 2009, 90, 607-621. [CrossRef]

71. Mani, V.; Gunasekaran, A.; Delgado, C. Enhancing supply chain performance through supplier social sustainability: An emerging economy perspective. Int. J. Prod. Econ. 2018, 195, 259-272. [CrossRef]

72. Castka, P.; Balzarova, M.A. The impact of ISO 9000 and ISO 14000 on standardisation of social responsibility-An inside perspective. Int. J. Prod. Econ. 2008, 113, 74-87. [CrossRef]

73. Andersen, M.; Skjoett-Larsen, T. Corporate social responsibility in global supply chains. Supply Chain Manag. Int. J. 2009, 14, 75-86. [CrossRef] 
74. Preuss, L. Ethical Sourcing Codes of Large UK-Based Corporations: Prevalence, Content, Limitations. J. Bus. Ethics 2009, 88, 735-747. [CrossRef]

75. Handley, S.M.; Benton, W.C., Jr. The influence of exchange hazards and power on opportunism in outsourcing relationships. J. Oper. Manag. 2012, 30, 55-68. [CrossRef]

76. Lam, J.S.L.; Bai, X. A quality function deployment approach to improve maritime supply chain resilience. Transp. Res. Part E Logist. Transp. Rev. 2016, 92, 16-27. [CrossRef]

77. Lam, J.S.L.; Dai, J. Environmental sustainability of logistics service provider: An ANP-QFD approach. Int. J. Logist. Manag. 2015, 26, 313-333. [CrossRef]

78. Bouchereau, V.; Rowlands, H. Methods and techniques to help quality function deployment (QFD). Benchmark. Int. J. 2000, 7, 8-20. [CrossRef]

79. Han, S.B.; Chen, S.K.; Ebrahimpour, M.; Sodhi, M.S. A conceptual QFD planning model. Int. J. Qual. Reliab. Manag. 2001, 18, 796-812. [CrossRef]

80. Sakao, T. A QFD-centred design methodology for environmentally conscious product design. Int. J. Prod. Res. 2007, 45, 4143-4162. [CrossRef]

81. Govers, C.P. What and how about quality function deployment (QFD). Int. J. Prod. Econ. 1996, 46, 575-585. [CrossRef]

82. Chan, L.-K.; Wu, M.-L. Quality function deployment: A literature review. Eur. J. Oper. Res. 2002, 143, $463-497$. [CrossRef]

83. Gimenez, C.; Tachizawa, E.M. Extending sustainability to suppliers: A systematic literature review. Supply Chain Manag. Int. J. 2012, 17, 531-543. [CrossRef]

84. Silvestre, B.S. A hard nut to crack! Implementing supply chain sustainability in an emerging economy. J. Clean. Prod. 2015, 96, 171-181. [CrossRef]

85. Sancha, C.; Gimenez, C.; Sierra, V. Achieving a socially responsible supply chain through assessment and collaboration. J. Clean. Prod. 2016, 112, 1934-1947. [CrossRef]

86. Bagchi, P.K.; Ha, B.C.; Skjoett-Larsen, T.; Soerensen, L.B. Supply chain integration: A European survey. Int. J. Logist. Manag. 2005, 16, 275-294. [CrossRef]

87. Ray, P.; Om Harsh, H.; Daniel, A.; Ray, A. Incorporating Block Chain Technology in Food Supply Chain. Int. J. Manag. Stud. 2019, 6, 5. [CrossRef]

88. Dai, H.-N.; Zheng, Z.; Zhang, Y. Blockchain for Internet of Things: A survey. IEEE Internet Things J. 2019, 6, 8076-8094. [CrossRef]

89. Saberi, S.; Kouhizadeh, M.; Sarkis, J.; Shen, L. Blockchain technology and its relationships to sustainable supply chain management. Int. J. Prod. Res. 2019, 57, 2117-2135. [CrossRef]

90. Angelis, J.; da Silva, E.R. Blockchain adoption: A value driver perspective. Bus. Horiz. 2019, 62, 307-314. [CrossRef]

Publisher's Note: MDPI stays neutral with regard to jurisdictional claims in published maps and institutional affiliations.

(C) 2020 by the authors. Licensee MDPI, Basel, Switzerland. This article is an open access article distributed under the terms and conditions of the Creative Commons Attribution (CC BY) license (http://creativecommons.org/licenses/by/4.0/). 